\title{
Efficacy of Bibhitakavaleha in Management of Kaphaja Kasa with special reference to Chronic Bronchitis
}

\author{
Research Article
}

\section{Sadhana Misar Wajpeyi ${ }^{*}$, Manish Deshmukh², Nandini Bhojraj ${ }^{3}$}

\author{
1. Professor, Department of Kayachikitsa, MGAC \& RC, Salod (H), Wardha, \\ Datta Meghe Institute of Medical Sciences (Deemed to be University), Sawangi (M), Wardha \\ 2. Deputy Director, Interdisciplinary of Research, Datta Meghe Institute of Medical Sciences, \\ (Deemed to be University), Sawangi (M) Wardha \\ 3. Chief Ayurved Consultant, Govigyan Anusandhan Kendra, Nagpur
}

\begin{abstract}
Kasa is the disease of Pranavaha strotas. It may develop as an independent disease, symptom or complication. In Kaphaja Kasa Kasavega is associated with Bahala Ghana Nishtivana. It can be correlated with Chronic Bronchitis due to similarities of signs and symptoms. Chronic Bronchitis is characterized by productive cough associated with sputum for at least 3 consecutive months for more than two successive years. The initial symptoms are repeated attacks of productive cough which shows a steady increase in severity during the winter months and present all the year round with recurrent respiratory infections. Ayurveda described many herbomineral formulations for management of Kasa. One such formulation Bibhitakavaleha is mentioned in Gadanigraha, which consists of Bibhitaki (Terminalia bellerica Roxb.), Gomutra (Cow urine) and Madhu (Honey). Methods: In this case series 30 patients having classical symptoms of Kaphaja Kasa were treated with Bibhitakavaleha 10gm twice a day with lukewarm water for 15 days with the aim to prove the efficacy of it in the management of Kaphaja Kasa. Subjective criteria like Kasavega, Kasa nishtiva, Shwaskricchrata, Peenas, Shirshool and Aruchi with Laboratory parameters like TLC (Total Leukocyte Count), Neutrophils, Absolute Eosinophil Count (AEC) and ESR (Erythrocyte Sedimentation Rate) were assessed before and after treatment. Result: Significant improvement was observed in all parameters after treatment. Bibhitaki possesses Kashaya Rasa, Madhura Vipaka, Ushna Veerya \& Laghu, Ruksha Guna which plays a major role in relieving Kasa. Conclusion: Hence it can be concluded that Kaphaja Kasa can be effectively treated with Bibhitakavaleha.
\end{abstract}

Key Words: Bibhitakavaleha, Chronic bronchitis, Kaphaja kasa, Kasavega.

\section{Introduction}

Kasa is the debilitating disease of Pranavaha strotas, when untreated, it may lead to dreadful diseases like Shwasa (Asthma), Shosha (cachexia), Rajyakshama (tuberculosis), Urakshata (chest injury) and Rakttapitta (bleeding like haemoptysis) (1).Kasa may develop as an independent disease, symptom or complication of a disease. Kasa is broadly classified as Ardrakasa and Shushkakasa. Kaphaja Kasa is a type of Ardra Kasa dominated by Kapha and Vatadushti. Vata and Kapha are the two key pathological factors involved in the Samprapti (etiopathogenesis) of Kaphaja Kasa (2).

Kaphaja Kasa is one of Pranvahastrotodusti Janita Vyadhi where Kasavega is associated with Bahala Ghana Nishtivana. It can be correlated with

\section{* Corresponding Author:}

\section{Sadhana Misar Wajpeyi}

Professor, Department of Kayachikitsa,

MGAC \& RC, Salod (H), Wardha,

Datta Meghe Institute of Medical Sciences (Deemed to be University), Sawangi (M), Wardha. India

Email Id: sadhanamisar@gmail.com
Chronic Bronchitis due to similarities of signs and symptoms. Chronic Bronchitis is characterized by cough associated with sputum for at least 3 consecutive months for more than 2 successive years. The initial symptoms are repeated attacks of productive cough which shows a steady increase in severity during the winter months and present all the year round with recurrent respiratory infections (3).

According to estimates from national interviews taken by the national center for health statistics approximately 9.5 million people or $4 \%$ of the population were diagnosed with Chronic Bronchitis. In one study acute bronchitis affected 44 of 1000 adults annually. Chronic Bronchitis is more prevalent in people older than 50 years (4).

According to National center for health statistics, 62 million cases of common cold and cough occurs each year. Cough is the fifth most common symptom for which patients seeks medical care. Ayurveda described many herbomineral formulations for management of Kasa. One such formulation Bibhitakavaleha is mentioned in Gadanigraha (5), which consists of Bibhitaki (Terminalia bellerica 
Roxb.), Gomutra (Cow urine) and Madhu (Honey). Bibhitaki is indicated by Acharya Vagbhata in all types of Shwasa \& Kasa (6). Bibhitaki possess Kashaya Rasa, Madhura Vipaka, Ushna Veerya \& Laghu, Ruksha Guna (7) which plays a major role in relieving Kasa.

\section{Need of the study}

As Pranavaha Strotas conveys Prana, any disease affecting this Strotas has to be treated with priority. Kaphaja Kasa may not be life threatening but increasingly annoying and irritating to the individual in his routine activity. When neglected it may lead to a series of complications later.

In recent years, there has been surprisingly increase of incidence related to Respiratory system because of the exposure to both active and passive smoke, air pollution, occupational hazards (8). No research Study on Bibhitakavaleha in management of Kaphaj Kasa was conducted yet. Hence a clinical study will be planned to prove efficacy of it in management of Kaphaja Kasa.

\section{Aims and Objectives}

Aim: Study the efficacy of Bibhitakavaleha in Kaphaja Kasa

\section{Objectives}

- To assess the efficacy of Bhibhitakavaleha in Kasa Vega and Kasa Nishtivana

- To assess the effect of Bibhitakavaleha in Shwaskricchrata (Dyspnoea)

- To know the effect of Bibhitakavaleha on Laboratory parameters like TLC (Total Leukocyte Count), Neutrophils, Absolute Eosinophil Count (AEC) and ESR (Erythrocyte Sedimentation Rate)

\section{Materials and Methods}

- Source of study: The Patients were selected from Kayachikitsa O.P.D. and I.P.D. of Mahatma Gandhi Ayurved College, Hospital \& Research Centre, Salod $(\mathrm{H})$ and from peripheral camps.

- Study Design: Single arm

- Study Type: Interventional study

- Sample size: 30

\section{Inclusion criteria}

- Patients aged between 20 and 70 years of either sex

- Patients having cardinal features of Chronic Bronchitis (Chronic cough, Excessive sputum production, Dyspnoea).

- Patients with COPD mild and moderate grade (GOLD guidelines).

\section{Exclusion Criteria}

- Known cases of Tuberculosis, Lung cancer, Bronchiectasis, Interstitial lung disease, CHD, DM, Pneumonia, Pneumothorax.

- Pregnant women and lactating mothers.

\section{Selection of Material}

Bibhitakavaleha was procured from Govigyan Anusandhan Santhan, Deolapar, Nagpur (MS).

\section{Table 1: Composition of Material}

\begin{tabular}{|r|l|l|c|}
\hline Sr.no. & $\begin{array}{l}\text { Name of } \\
\text { drug }\end{array}$ & Latin name & Part used \\
\hline 1 & Bhibhitaki & $\begin{array}{l}\text { Terminalia belerica } \\
\text { Roxb. }\end{array}$ & Fruit \\
\hline 2 & Gomutra & Cow Urine & Mutra \\
\hline 3 & Honey & Mel & - \\
\hline
\end{tabular}

\section{Safety Profile}

Toxicity study of Bibhitaki- Thanabhorn S. et al. (2009) conducted acute and sub acute toxicity studies as per the OECD guidelines. Single oral administration of the ethanolic extract of T. belerica at a dose of $5,000 \mathrm{mg} / \mathrm{kg}$ did not produce any toxicity. In sub acute toxicity, repeated administration of $1,000 \mathrm{mg} /$ $\mathrm{kg}$ of $\mathrm{T}$. belerica over 14 days did not cause changes in terms of general behaviors, mortality, weight gain, hematological or clinical blood chemistry parameters. The results of histological examinations showed normal appearance of the internal organs when compared to those of the control group (9).

\section{Toxicity study of Gomutra}

In acute toxicity study, no toxicity was observed even when cow urine was given $32 \mathrm{ml} / \mathrm{kg}$ which was 32 times of the study dose, which suggests that cow urine is having very high therapeutic index. Although no histopathological studies were undertaken, it was surmised that Gomutra Arka is safe in animals (10).

\section{Toxicity of honey}

A study conducted on mice results suggested the harmful side effects of cadmium on liver and kidney, and it was concluded that honey via its antioxidant activity has the ability to protect against cadmium induced hepatotoxicity and nephrotoxicity (11). No any toxic effects of honey were noted on liver and kidney (12).

\section{Posology}

-Dose 10gm two times a day after meal with lukewarm water

-Duration - 15 days

-Follow up -During of treatment- After $7^{\text {th }}$ and $15^{\text {th }}$ day. After treatment-30 days

\section{Investigations}

-Total Leukocytes Count

- Differential count

-Erythrocyte Sedimentation Rate

-Absolute Eosinophil count

\section{Assessment Criteria}

-Patients were assessed for subjective and objective criteria on $0,7,15$ day 


\section{Table 2: Subjective Criteria}

\begin{tabular}{|c|c|c|c|c|c|}
\hline SN & Criteria & $\mathbf{0}$ & 1 & 2 & 3 \\
\hline 1 & $\begin{array}{l}\text { Kasa Vega } \\
\text { (Bouts of cough) }\end{array}$ & No coughing & $\begin{array}{l}\text { Coughing } 1 \text { to } 3 \\
\text { times in } 24 \mathrm{hrs} .\end{array}$ & $\begin{array}{l}\text { Coughing } 4 \text { to } 6 \\
\text { times in } 24 \mathrm{hrs}\end{array}$ & $\begin{array}{l}\text { Coughing more than } 6 \\
\text { times in } 24 \mathrm{hrs} \text {. }\end{array}$ \\
\hline 2 & $\begin{array}{l}\text { Kasa Nishtivana } \\
\text { (Sputum) }\end{array}$ & No sputum & $\begin{array}{l}\text { Sputum early in } \\
\text { the morning }\end{array}$ & $\begin{array}{l}\text { Sputum } 2 \text { - } 3 \text { times } \\
\text { daily }\end{array}$ & $\begin{array}{l}\text { Sputum with each } \\
\text { coughing }\end{array}$ \\
\hline 3 & $\begin{array}{l}\text { Shwaskricchrata } \\
\text { (Breathlessness) }\end{array}$ & $\begin{array}{l}\text { No breathlessness } \\
\text { except with } \\
\text { strenuous exercise }\end{array}$ & $\begin{array}{l}\text { Breathlessness } \\
\text { when hurrying on } \\
\text { the level or } \\
\text { walking up a slight } \\
\text { hill }\end{array}$ & $\begin{array}{l}\text { Stops for breath } \\
\text { after walking about } \\
100 \text { m or after a few } \\
\text { minutes on level } \\
\text { ground }\end{array}$ & $\begin{array}{l}\text { Too breathless to leave } \\
\text { the house or breathless } \\
\text { when dressing or } \\
\text { undressing }\end{array}$ \\
\hline 4 & $\begin{array}{l}\text { Shirshool } \\
\text { (Headache) }\end{array}$ & No Shirshool & $\begin{array}{l}\text { Shirshool } \\
\text { Occasionally }\end{array}$ & $\begin{array}{l}\text { Shirshool } \\
\text { Frequently }\end{array}$ & $\begin{array}{l}\text { Continuous Shirshool } \\
\text { which disturbs day to } \\
\text { day activities }\end{array}$ \\
\hline 5 & $\begin{array}{l}\text { Peenas } \\
\text { (Cold) }\end{array}$ & Absent & Present & - & - \\
\hline 6 & $\begin{array}{l}\text { Agnimandya } \\
\text { (Loss of appetite) }\end{array}$ & Absent & Present & - & -- \\
\hline 7 & $\begin{array}{l}\text { Aruchi } \\
\text { (Tastelessness) }\end{array}$ & Absent & Present & - & - \\
\hline
\end{tabular}

\section{Objective criteria}

Objective criteria Total Leukocyte Count (TLC), Differential Leukocyte Count (DLC), Erythrocyte Sedimentation Rate (ESR) and Absolute Eosinophil Count (AEC) were assessed before and after treatment.

\section{Observations and Results}

Statistical analysis was done by using descriptive and inferential statistics using chisquare test, student's paired $t$ test and Wilcoxon signed rank test and software used in the analysis was SPSS 24.0 version and Graphpad Prism 7.0 version and $\mathrm{p}<0.05$ is considered as level of significance.

Age wise distribution of patient showed that maximum patients $13(43.33 \%)$ were in the age group of 51-60 yrs. In this study number of male patients were more that is $17(56.67 \%)$ as compared to female. Occupation wise distribution showed that maximum patients were housewives $11(36.67 \%)$. In this study maximum patients $14(46.67 \%)$ belonged to lower socioeconomic group. In this study family history was present in $16(53.33 \%)$ patients, maximum patients $14(46.67 \%)$ had not addicted to any type of habit, 16(53.33\%) patients were taking vegetarian diet, $18(60 \%)$ patients had no history of any type of allergy and sleep was disturbed in $16(53.33 \%)$ patients. In this study14 (46.67\%) patients had madhyam akruti, jivha was saam in 17(56.67\%) patients, vatakapha prakruti was found in $13(43.33 \%)$ patients, $17(56.67 \%)$ patients had mandagni and $16(53.33 \%)$ patients had madhyam koshtha.

Table 3: Comparison of Kasavega before and after treatment Wilcoxon signed rank test

\begin{tabular}{|c|c|c|c|c|c|}
\hline & Mean & $\mathrm{N}$ & Std. Deviation & Std. Error Mean & z-value \\
\hline BT & 2.60 & 30 & 0.49 & 0.09 & 21.52 \\
\hline AT & 0.36 & 30 & 0.49 & 0.08 & $\mathrm{P}=0.0001, \mathrm{~S}$ \\
\hline
\end{tabular}

Table 4: Comparison of Kaphanishtivana before and after treatment Wilcoxon signed rank test

\begin{tabular}{|c|c|c|c|c|c|}
\hline & Mean & $\mathrm{N}$ & Std. Deviation & Std. Error Mean & z-value \\
\hline BT & 2.70 & 30 & 0.53 & 0.09 & 17.94 \\
\hline AT & 0.40 & 30 & 0.49 & 0.09 & $\mathrm{P}=0.0001, \mathrm{~S}$ \\
\hline
\end{tabular}

Table 5: Comparison of Shwasakruchrata before and after treatment Wilcoxon signed rank test

\begin{tabular}{|c|c|c|c|c|c|}
\hline & Mean & $\mathrm{N}$ & Std. Deviation & Std. Error Mean & z-value \\
\hline BT & 1.46 & 30 & 0.62 & 0.11 & 12.33 \\
\hline AT & 0.06 & 30 & 0.25 & 0.04 & $\mathrm{P}=0.0001, \mathrm{~S}$ \\
\hline
\end{tabular}




\section{Table 6: Comparison of Shirshool before and after treatment}

Wilcoxon signed rank test

\begin{tabular}{|l|c|c|c|c|c|} 
& Mean & $\mathrm{N}$ & Std. Deviation & Std. Error Mean & z-value \\
\hline BT & 1.20 & 30 & 0.84 & 0.15 & 7.30 \\
\hline AT & 0.03 & 30 & 0.18 & 0.03 & $\mathrm{P}=0.0001, \mathrm{~S}$ \\
\hline
\end{tabular}

Table 7: Comparison of Peenas before and after treatment

\begin{tabular}{c|c|c|c|}
\hline Peenas & BT & AT & X2-value \\
\hline Present & $23(76.67 \%)$ & $0(0 \%)$ & 49.09 \\
\hline Absent & $7(23.33 \%)$ & $30(100 \%)$ & $\mathrm{P}=0.0001, \mathrm{~S}$ \\
\hline Total & $30(100 \%)$ & $100(100 \%)$ & \\
\hline
\end{tabular}

Table 8: Comparison of Agnimandya before and after treatment

\begin{tabular}{|c|c|c|c|}
\hline Agnimandya & BT & AT & X2-value \\
\hline Present & $15(50 \%)$ & $0(0 \%)$ & 20.00 \\
\hline Absent & $15(50 \%)$ & $30(100 \%)$ & $\mathrm{P}=0.0001, \mathrm{~S}$ \\
\hline Total & $30(100 \%)$ & $100(100 \%)$ & \\
\hline
\end{tabular}

Table 9: Comparison of Aruchi before and after treatment

\begin{tabular}{c|c|c|c|}
\hline Aruchi & BT & AT & X2-value \\
\hline Present & $15(50 \%)$ & $0(0 \%)$ & 20.00 \\
\hline Absent & $15(50 \%)$ & $30(100 \%)$ & $\mathrm{P}=0.0001, \mathrm{~S}$ \\
\hline Total & $30(100 \%)$ & $100(100 \%)$ & \\
\hline
\end{tabular}

Table 10: Comparison of $\mathrm{Hb} \%$ before and after treatment

Student's paired $t$ test

\begin{tabular}{|l|l|l|c|c|c|} 
& Mean & N & Std. Deviation & Std. Error Mean & t-value \\
\hline BT & 12.85 & 30 & 1.40 & 0.25 & 3.49 \\
\hline AT & 13.13 & 30 & 1.23 & 0.22 & $\mathrm{P}=0.002, \mathrm{~S}$ \\
\hline
\end{tabular}

Table 11: Comparison of TLC before and after treatment Student's paired $t$ test

Table 12: Comparison of Neutrophil before and after treatment Student's paired $\mathbf{t}$ test

\begin{tabular}{l|l|l|c|c|c|} 
& Mean & $\mathrm{N}$ & Std. Deviation & Std. Error Mean & $\mathrm{t}$-value \\
\hline BT & 65.15 & 30 & 8.50 & 1.55 & 2.72 \\
AT & 61.80 & 30 & 6.30 & 1.15 & $\mathrm{P}=0.011, \mathrm{~S}$
\end{tabular}

Table 13: Comparison of Eosinophils before and after treatment

Wilcoxon Signed Rank test

\begin{tabular}{l|c|c|c|c|c|} 
& Mean & $\mathrm{N}$ & Std. Deviation & Std. Error Mean & z-value \\
\hline BT & 2.40 & 30 & 1.03 & 0.18 & 3.45 \\
\hline AT & 1.83 & 30 & 0.53 & 0.09 & $\mathrm{P}=0.002, \mathrm{~S}$ \\
\hline
\end{tabular}

Table 14: Comparison of AEC before and after treatment Student's paired $\mathbf{t}$ test

\begin{tabular}{l|c|c|c|c|c|} 
& Mean & $\mathrm{N}$ & Std. Deviation & Std. Error Mean & $\mathrm{t}$-value \\
\hline BT & 196.63 & 30 & 81.34 & 14.85 & 4.16 \\
AT & 138.40 & 30 & 45.90 & 8.38 & $\mathrm{P}=0.0001, \mathrm{~S}$
\end{tabular}

Table 15: Comparison of ESR before and after treatment

Student's paired $t$ test

\begin{tabular}{|l|c|c|c|c|c|} 
& Mean & N & Std. Deviation & Std. Error Mean & t-value \\
\hline BT & 46.00 & 30 & 22.14 & 4.04 & 8.18 \\
\hline AT & 28.30 & 30 & 12.65 & 2.30 & $\mathrm{P}=0.0001, \mathrm{~S}$ \\
\hline
\end{tabular}


Mean of Kasavega before treatment was 2.60 which reduced to 0.36 after treatment. Significant improvement was observed in Kasavega after treatment with significant $\mathrm{p}$ value $(21.52, \mathrm{P}=0.0001)$. Mean of Kaphanishtivana before treatment was 2.70 which reduced to 0.40 after treatment. Significant improvement was observed in Kaphanishtivana after treatment with significant $\mathrm{P}$ value $(17.94, \mathrm{P}=0.0001)$. Mean of Shwasakruchrata before treatment was 1.46 which reduced to 0.06 after treatment. Significant improvement was observed in Shwasakruchrata after treatment with significant $\mathrm{P}$ value $(12.33, \mathrm{P}=0.0001)$. Mean of Shirshool before treatment was 1.20 which reduced to 0.03 after treatment. Significant improvement was observed in Shirshool after treatment with significant $\mathrm{P}$ value $(7.30, \mathrm{P}=0.0001)$. Peenas was present in $23(76.67 \%)$ patients before treatment but after treatment it was absent in all. Complete improvement was observed in Peenas with significant $\mathrm{P}$ value (49.09, $\mathrm{P}=0.0001)$. Agnimandya was present in $15(50 \%)$ patients before treatment but after treatment it was absent in all. Complete improvement was observed in Agnimandya with significant $\mathrm{P}$ value (20.00, $\mathrm{P}=0.0001)$. Aruchi was present in $15(50 \%)$ patients before treatment but after treatment it was absent in all. Complete improvement was observed in Aruchi with significant $P$ value $(20.00, P=0.0001)$.

Mean of $\mathrm{Hb} \%$ before treatment was $12.85 \%$ which increased to $13.13 \%$ after treatment. Significant improvement was observed in Shirshool after treatment with significant $\mathrm{P}$ value $(3.49, \mathrm{P}=0.002)$. Mean of TLC before treatment was 8523.33 which decreased to 7710.00 after treatment. Significant improvement was observed in TLC after treatment with significant $P$ value (2.74, $\mathrm{P}=0.010)$. Mean of Neutrophil before treatment was 65.15 which decreased to 61.80 after treatment. Significant improvement was observed in Neutrophil after treatment with significant $\mathrm{P}$ value $(2.72, \mathrm{P}=0.011)$. Mean of Eosinophils before treatment was 2.40 which decreased to 1.83 after treatment. Significant improvement was observed in Eosinophils after treatment with significant $\mathrm{P}$ value $(3.45, \mathrm{P}=0.002)$. Mean of AEC before treatment was 196.63 which decreased to 138.40 after treatment. Significant improvement was observed in AEC after treatment with significant $\mathrm{P}$ value $(4.16, \mathrm{P}=0.0001)$. Mean of ESR before treatment was 46.00 which decreased to 28.30 after treatment. Significant improvement was observed in ESR after treatment with significant $\mathrm{P}$ value (8.18, $\mathrm{P}=0.0001$ ).

\section{Discussion}

Kasa is a vyadhi of pranavaha strotas and Kaphaja Kasa is a type of Ardra Kasa in which there is Kapha and Vatadushti. In this study Bibhitakavaleha was used in Kaphaja kasa which is mentioned in Gadanigraha (13).
In this study total 30 patients having classical symptoms of Kaphaja Kasa were treated with Bibhitakavaleha, 10gm twice a day with lukewarm water for 15 days. Patients were assessed for subjective as well as objective criteria before and after completion of treatment. Patients were assessed for subjective criteria like Kasavega, Kaphanishtivana, Shwaskruchrata, Shirshool, Peenas, Agnimandya and Aruchi. Objective criteria were $\mathrm{Hb} \%$, Total Leucocyte Count, Neutrophils, Eosinophils, Absolute Eosinophil count and Erythrocyte Sedimentation Rate.

In this study significant improvement was observed in all subjective as well as objective parameters after completion of treatment. Ingredients of Bibhitakavaleha are Bibhitaki (Terminalia bellerica Roxb.), Gomutra and Madhu. Acharya Charak included Bibhitaki in Kasahar and jwarhar dravyas (14).

Bibhitaki is indicated by Acharya Vagbhata in all types of Shwasa \& Kasa. Bibhitaki is Kashaya Rasa, Madhura Vipaka, Ushna Veerya \& Laghu, Ruksha Guna which plays a major role in relieving Kasa. It has kaphavata shamak property which helps in pacification thereby balancing doshas. Mruduvirechaka property of Bibhitaki helps in vatanulomana and normalizes gati of vata (15). It possesses Rasayana property which helps in boosting immune system (16).

Ayurvedic texts classify Bibhitaki under the group of herbs that are useful in treating cold, cough and fever (17). It is said to be having a balancing effect on Kapha and Pitta. Gomutra possesses antimicrobial and immune-modulatory property that helps in reducing symptoms of Kaphaja kasa (18).

Madhu (honey) helps in reducing Kasavega and Kaphanishtivana. Honey has antimicrobial, antioxidant and anti-inflammatory properties. Research study reported that in temperate climates and places with considerable temperature fluctuations, honey is a well-known remedy for colds and mouth, throat or bronchial irritations and infections (19). There is increasing evidence that a single dose of honey might reduce mucus secretion and reduce cough in children. In a research study conducted on healthy men, honey showed good demulcent effect and antioxidant properties, and increased cytokine release, which might be due to its antimicrobial effects (20).

In this study 30 patients of Kaphaja kasa were treated with Bibhitakavaleha. It gave a significant improvement in all subjective parameters. Objective parameters like $\mathrm{Hb} \%$, TLC, DLC, AEC and ESR have no much significant role in assessment of cough. So to evaluate the efficacy of Bibhitakavaleha, more specific objective parameters like Lung Function Test should be taken and further study should be conducted on large sample size. To prove efficacy of Bibhitakavaleha a comparative study should be conducted by taking standard drug as a control group with blinding. 


\section{Conclusion}

Kaphaj kasa can be managed effectively by herbal formulation Bibhitakavaleha mentioned in Gadanigraha.

\section{Acknowledgement}

I am thankful to my institute MGACH \& RC, Salod (H), DMIMS (DU), Wardha and all those help me in this research work.

\section{Conflict of interest - No any}

Funding - Drug supplied by Govigyan Anusandhan Santhan, Deolapar, Nagpur.

\section{References}

1. Shastri Sadashiva Paradakara, Ashtanga Hridaya of Vagbhata, Nidana Sthana, Raktapittaniadana, , Sarvangasundara of arunadutta and Ayrveda Rasaya of Hemadri commentaries, Sixth edition, chapter 3/18, 2010, 469-472.

2. Yadhavji Trikamji, Charakasamhita of Agnivesh, Chaukhambha Sanskrit Sansthan Varanasi; 2011, pp. 433

3. Nicki R. Colledge Brian R.Walker, StuartH.Ralston, Davidson's principles and practice of Medicine, $21^{\text {st }}$ edition 2010 p.671-673

4. Jazeela Fayyaz, Chronic Bronchitis, Medscape, March 2011http: // emedicine.medscape.com/ article/297108 - overview\#a0156.(cited on 12.4.2019 at $11.30 \mathrm{pm}$ )

5. Pandeya Ganga Sahaya, Sodhala, Gadanigraha, The Vidyotini Hindi commentary, Part I (Prayoga Khand), Lehadhikar.Chaukhamba Sanskrit Sansthan,Varanasi.,p.307

6. Tripathi Bramhanand, Ashtanga Hridaya, 1st ed. Reprint (2007) Pg no 607

7. Chunekar K.C, Bhavaprakasha Nighamtu, Chaukamba Bharti Academy, Varanasi, Haritkyadivarga Revised edition 2010 pg no.9.

8. Sharma S.K, Chronic obstructive Pulmonary Disease, API text book of Medicine, Edited by Siddharth N.Shah, 8 Edition, The Association of Physicians of India, Mumbai, 2008,PP 361-367.
9. Thanabhorn S, et.al. Acute and Sub acute Toxicities of the Ethanol Extract of fruit of Terminalia belerica Journal of Pharmacuetical sciences,2009

10. Devender O. et.al., Evaluation of antidiabetic, antioxidant effect and safety profile of gomutra ark in Wistar albino rats Anc Sci Life. 2012 Jan-Mar; 31(3): 84-89.

11. Wafaa M. et.al. The potential protective effect of natural Honey againstCadmiuminduced Hepatotoxicity and Nephrotoxicity; Mansoura J. Forensic Med. Clinical Toxicology. 2007;15 (2) .

12. Bhalchandra Waykar and Yahya Ali Alqadhi,Biological Properties and Uses of Honey: A Concise Scientific reviewIndian J. Pharm. Biol. Res. 2016; 4(3):58-68

13. Pandeya Ganga Sahaya, Sodhala, Gadanigraha, , The Vidyotini Hindi commentary,Part I(PrayogaKhand), Lehadhikar.Chaukhamba Sanskrit Sansthan,Varanasi.,p.307

14. Yadavji Trivikramji, Charaka Samhita of Agnivesha, Sutrasthana Shdvirechanashatashritiya Adhyaya (4/16). Varanasi: Chaukhambha Sanskrit Sansthan; 2009.p.34.

15. Sharma P, Dhanvantari Nighantu,Guduchyadi varga,Verse 202-206,Chaukhamba orientalia, Reprinted edition 2008,p-53.

16. Arunadatta, Astanga hridaya, Sarvanga Sundara Vyakya, Vaidya H.P. Krishnadas Academy of Varanasi, 1995; 575-602.

17. Gilani H.A., et.al. Mechanisms underlying the antispasmodic and bronchodilatory properties of Terminalia belerica fruit. J Ethnopharmacol. (2008). 116:528-538.

18. Prashith Kekuda et.al. Cow Urine Concentrate : A potent agent with Antimicrobial and Anthelmintic activity.Journal of Pharmacy Research 2010, 3(5),1025-1027.

19. Bhalchandra Waykar and Yahya Ali Alqadhi. Beekeeping and Bee Products; Boon for Human Health and Wealth. Indian J. Pharm. Biol. Res.2016; 4(3):58-68.

20. Ran D. Goldman, Honey for treatment of cough in children, Can Fam Physician. 2014 Dec; 60(12): 1107-1110. 